\title{
Tyrosine phosphorylation is involved in reorganization of the actin cytoskeleton in response to serum or LPA stimulation
}

\author{
Magdalena Chrzanowska-Wodnicka and Keith Burridge \\ Department of Cell Biology and Anatomy, University of North Carolina, Chapel Hill, NC 27599-7090, USA
}

\section{SUMMARY}

Tyrosine phosphorylation is known to regulate the formation of focal adhesions in cells adhering to extracellular matrix (ECM). We have investigated the possible involvement of tyrosine phosphorylation and the focal adhesion kinase (FAK) in the cytoskeletal changes induced by serum or lysophosphatidic acid (LPA) in quiescent Swiss 3T3 fibroblasts. As shown previously by others, quiescent cells stimulated with serum or LPA reveal a rapid reappearance of focal adhesions and stress fibers. Here we show that this is accompanied by an increase in phosphotyrosine in focal adhesions and specifically an increase in the tyrosine phosphorylation of FAK. The LPAstimulated reappearance of focal adhesions and stress fibers is blocked by inhibitors of phospholipase $\mathrm{C}$ but not by pertussis toxin (PTX), indicating that this LPA signaling pathway is mediated by phospholipase $\mathrm{C}$ activation and does not involve PTX-sensitive $G$ proteins. In the absence of serum or LPA, these cytoskeletal effects and the tyrosine phosphorylation of FAK can be mimicked by sodium orthovanadate in conjunction with hydrogen peroxide, agents that inhibit protein tyrosine phosphatases and thereby elevate levels of phosphotyrosine. Two tyrosine kinase inhibitors, erbstatin and genistein block both the serum-induced tyrosine phosphorylation of FAK and the assembly of focal adhesions and stress fibers. Two other tyrosine kinase inhibitors, tyrphostins 47 and 25, previously shown to inhibit FAK, failed to prevent FAK phosphorylation or the reassembly of focal adhesions and stress fibers in response to serum. However, these inhibitors did prevent FAK phosphorylation and cytoskeletal assembly in response to lysophosphatidic acid (LPA), one component of serum previously shown to stimulate assembly of focal adhesions and stress fibers. Our findings suggest that the response to serum is complex and that although FAK phosphorylation is important, other tyrosine kinases may also be involved.

Key words: FAK tyrosine phosphorylation, focal adhesion, stress fiber

\section{INTRODUCTION}

Fibroblasts and many other cell types in culture develop specialized adhesions to the underlying substratum, known as focal adhesions (focal contacts, adhesion plaques) (for reviews see: Burridge et al., 1988; Geiger 1989; Tsukita et al., 1990). These are the regions of tightest adhesion to the substratum and, at their cytoplasmic face, focal adhesions anchor bundles of actin filaments (stress fibers). Since focal adhesions only develop on surfaces coated with extracellular matrix (ECM) components, they serve as a convenient model for studying the adhesive interactions of cells with ECM. Focal adhesions are not only sites of structural linkage between the ECM and the cytoskeleton, but an abundance of recent evidence indicates that these are also sites of transmembrane signaling (Burridge et al., 1992a; Hynes, 1992; Juliano and Haskill, 1993; Bockholt and Burridge, 1994).

Although much has been learned about the components of focal adhesions, many questions about the assembly and disassembly of these structures remain unanswered. One system used to study the assembly of focal adhesions has been to observe their formation in cells plated directly onto a substrate coated with an ECM protein, such as fibronectin. Using this system evidence has been found for a role of tyrosine phosphorylation in the assembly of focal adhesions. Several focal adhesion proteins become tyrosine phosphorylated as cells adhere to and spread on fibronectin (Guan et al., 1991; Burridge et al., 1992b; Bockholt and Burridge, 1993), and tyrosine kinase inhibitors prevent the formation of focal adhesions (Burridge et al. 1992b; Romer et al., 1992, 1994). One of the major tyrosine phosphorylated, focal adhesion proteins is itself a tyrosine kinase, the focal adhesion kinase (FAK) (Hanks et al., 1992; Schaller et al., 1992; Whitney et al., 1993). FAK becomes tyrosine phosphorylated and activated in response to either integrin-mediated adhesion (Guan and Shalloway, 1992; Burridge et al., 1992b; Hanks et al., 1992; Kornberg et al., 1992; Lipfert et al., 1992; Romer et al., 1992, 1994), or integrin clustering by antibodies (Kornberg et al., 1991).

A disadvantage of examining the formation of focal adhesions as cells spread on an ECM-coated surface is that focal adhesions form asynchronously and spreading is usually a slow and complex process. A different model system for studying focal adhesion assembly has been developed by 
Ridley and Hall (1992). These investigators found that quiescent, serum-starved Swiss 3T3 fibroblasts have very few stress fibers or focal adhesions, but serum stimulation rapidly restores these structures. Ridley and Hall identified lysophosphatidic acid (LPA) as a component of serum responsible for this effect. Furthermore, they demonstrated that the low molecular mass GTP-binding protein RhoA is involved in mediating the formation of focal adhesions and stress fibers under these conditions. Inhibiting RhoA activity with C3 exotransferase blocks the serum-stimulated reappearance of focal adhesions (Ridley and Hall, 1992; Chardin et al., 1989), whereas microinjection of activated RhoA induces focal adhesion formation in serum-starved, quiescent cells (Ridley and Hall, 1992; Paterson et al., 1990).

In this paper, we have asked whether the rapid formation of focal adhesions in quiescent cells responding to serum or LPA also involves tyrosine phosphorylation. We have found that the assembly of focal adhesions and stress fibers is accompanied by an elevation in the tyrosine phosphorylation of FAK. In addition, we have found that this assembly is blocked by inhibiting tyrosine phosphorylation and can be mimicked by inhibiting tyrosine phosphatases.

\section{MATERIALS AND METHODS}

\section{Cell culture, protein tyrosine kinase inhibitors, protein tyrosine phosphatase inhibitors}

Swiss 3T3 fibroblasts (American Type Culture Collection), were grown in Dulbecco's modified Eagle's medium (DMEM) (Life Technologies, Inc.), with 100 units $/ \mathrm{ml}$ penicillin, $100 \mu \mathrm{g} / \mathrm{ml}$ streptomycin and $250 \mathrm{ng} / \mathrm{ml}$ amphotericin B as fungizone, supplemented with $10 \%$ bovine calf serum, BCS (JRH Biosciences, Lenexa, KS). To obtain quiescent cells we modified a previously described protocol (Ridley and Hall, 1992). Briefly, in each experiment cells were seeded at identical density in $100 \mathrm{~mm}$ tissue culture dishes and maintained in the culture medium with serum, without feeding. The cells were used 710 days after they reached confluence. The cells were then extensively washed and starved in serum-free culture medium for 20-36 hours. Quiescent, serum-starved cells were stimulated with culture medium containing $0.5 \%$ fetal bovine serum (FBS) (JRH Biosciences) for 30 minutes. In some experiments $0.2-2.0 \mu \mathrm{g} / \mathrm{ml}$ lysophosphatidic acid (LPA; 1-oleoyl-2-hydroxy-sn-glycero-3-phosphate, monosodium salt in water) (Avanti, Alabaster, AL) was used to stimulate cells instead of serum.

For some experiments, cells were treated with indicated concentrations of tyrphostin 47 (Biomol Research Labs, Inc.) or tyrphostin 25 (Gibco BRL, Gaithersburg, MD) in dimethyl sulfoxide (DMSO) during serum starvation and following stimulation. For some experiments erbstatin analog (EA; methyl 2,5-dihydroxycinnamate, 5-50 $\mu \mathrm{g} / \mathrm{ml}$, Biomol) or genistein (100-250 $\mu \mathrm{g} / \mathrm{ml}$, Biomol) were added to the culture medium for the last 1 or 3 hours of starvation, and during stimulation with $0.5 \%$ FBS.

In some experiments either $1 \mathrm{mM}$ sodium orthovanadate and $3 \mathrm{mM}$ hydrogen peroxide or $50 \mu \mathrm{M}$ phenylarsine oxide were added after starvation to the serum-free culture media for 10-30 minutes, instead of $0.5 \%$ FBS.

\section{Phospholipase $\mathbf{C}$ inhibitors and pertussis toxin}

To study the role of phospholipase C (PLC) in the response to LPA, the aminosteroid U-73122 (1-[6-[[17 betha-3-Methoxyestra1,3,5(10)-trien-17-yl]amino]hexyl]-1H-pyrrole-2,5-dione), or its inactive analog, U-73343 (1-[6-[[17 betha-3-Methoxyestra-1,3,5(10)trien-17-yl]amino]hexyl]-1H-pyrrolidine-2,5-dione), (both from
Biomol), at $10 \mu \mathrm{M}$, was added to the culture media during stimulation with LPA. In some experiments pertussis toxin (PTX), an inhibitor of some heterotrimeric $\mathrm{G}$ proteins, was present in the culture media during the last 2 hours of starvation and during stimulation with LPA. The PTX concentration range was $100-500 \mathrm{ng} / \mathrm{ml}$.

\section{Immunoprecipitation and immunoblotting}

Cells were lysed on ice with cold lysis buffer consisting of Trisbuffered saline (TBS; $150 \mathrm{mM} \mathrm{NaCl}, 50 \mathrm{mM}$ Tris-Cl, $\mathrm{pH}$ 7.6) with $0.1 \%$ sodium azide, $0.1 \%$ Triton $\mathrm{X}-100,0.1 \%$ sodium deoxycholate, $2 \mathrm{mM}$ EDTA, $2 \mathrm{mM}$ EGTA, $1 \mathrm{mM}$ sodium orthovanadate and 25 $\mu \mathrm{g} / \mathrm{ml}$ leupeptin. The lysates were clarified by a 15 minute centrifugation in a microfuge. Supernatants were incubated with $2 \mathrm{~A} 7$, antiFAK monoclonal IgG (Upstate Biotechnology, Inc.) or with antiphosphotyrosine, py20 (ICN Biochemicals, Costa Mesa, CA) for at least 4 hours. Antigen-antibody complexes were then precipitated by rotating for 1 hour at $4^{\circ} \mathrm{C}$ with rabbit anti-mouse-conjugated Protein A-Sepharose (Chemicon International, Temecula, CA). Beads were pelleted by centrifugation and washed 3 times in lysis buffer. Proteins bound to the Sepharose were then released by boiling in sample buffer and electrophoresed on $7.5 \%$ polyacrylamide gels as described by Laemmli (1970) with a bisacrylamide concentration of $0.19 \%$. Proteins were transferred electrophoretically to nitrocellulose and blocked with $2 \%$ cold water fish gelatin (Sigma) in TBSTB (TBS with $0.1 \%$ bovine serum albumin and $0.05 \%$ Tween-20) for 20-30 minutes. The nitrocellulose was then probed for 45 minutes with anti-phosphotyrosine IgG conjugated to horseradish peroxidase, py20-HRP (ICN Biochemicals), at 1:10,000 dilution. Following this incubation, the blots were extensively washed with several changes of TBSTB and TBS. Enhanced chemiluminesence (Amersham, UK) was used to develop the blots. Immunoblots were stripped in $62.5 \mathrm{mM}$ Tris- $\mathrm{HCl}$, $\mathrm{pH} 6.75,2 \%$ sodium dodecyl sulfate and $100 \mathrm{mM} \beta$-mercaptoethanol at $55^{\circ} \mathrm{C}$ for 45 minutes. Stripped blots were washed in TBS for 16 hours and reprobed with 2A7 antibody at 1:1,000 in TBSTB. After washing in TBSTB the blots were incubated with HRP-conjugated goat anti-mouse IgG (Jackson Immunoresearch, West Grove, PA) at $1: 10,000$ dilution.

\section{$\left[{ }^{35}\right.$ S]methionine metabolic labeling and phosphotyrosine quantitation}

For quantitation of tyrosine phosphorylation, cells were washed briefly with glutamine-, cysteine- and methionine-free culture medium (ICN Biochemicals) and incubated with culture medium (10\% serum, 10\% DMEM and 80\% DMEM without cysteine or methionine) containing $0.5 \mathrm{mCi}\left[{ }^{35} \mathrm{~S}\right]$ methionine and cysteine overnight. Cells were then washed in serum-free media, starved and stimulated for 2-30 minutes as described above. Lysates were prepared (see above) and precleared with Protein A coupled to Sepharose for 1-3 hours. The lysates were divided in half and immunoprecipitated with either anti-FAK or anti-phosphotyrosine antibodies. The immunoprecipitates were analyzed on 7.5\% SDS gels, which were then stained with Coomasie Blue to reveal the molecular mass markers, destained and incubated for 30 minutes in Amplify (Amersham, Arlington Heights, Illinois). After drying, gels were exposed to X-ray film overnight. Bands corresponding to FAK were excised from the gel and ${ }^{35} \mathrm{~S}$-incorporation was measured in the scintillation counter. To normalize for FAK content, the number of counts in the phosphotyrosine immunoprecipitate was divided by the number of counts obtained from the corresponding FAK immunoprecipitate. The results were expressed as percent increase above the unstimulated, quiescent cells.

\section{Immunofluorescence}

For visualization of stress fibers and focal adhesion components, cells plated on coverslips under conditions described above were fixed in $3.7 \%$ formaldehyde in PBS for 7 minutes, washed in TBS with $0.1 \%$ azide and permeabilized with $0.5 \%$ Triton X-100. Actin was stained 
with $400 \mathrm{mU} / \mathrm{ml}$ TRITC-phalloidin (Molecular Probes, Inc., Eugene, OR). Focal adhesions were visualized using either anti-phosphotyrosine, py20 (ICN Biochemicals) or monoclonal anti-vinculin, kindly provided by Dr Alexey Belkin (Glukhova et al., 1990); followed by TRITC- or FITC-labeled goat anti-mouse IgG, respectively (Chemicon). Immunolabeling was performed at $37^{\circ} \mathrm{C}$ for 45 minutes for each antibody.

\section{RESULTS}

\section{Serum-induced reorganization of the cytoskeleton is accompanied by changes in FAK phosphorylation}

Ridley and coworkers have reported previously the morphological changes in cytoskeletal organization that occur when quiescent Swiss 3T3 fibroblasts are stimulated with low concentrations of serum (Ridley and Hall, 1992; Ridley et al., 1992). We have examined the changes in phosphotyrosine in quiescent cells responding to serum stimulation. Phosphotyrosine staining (Fig. 1C,F,I) was compared with vinculin (Fig. $1 \mathrm{~A}, \mathrm{D}, \mathrm{G}$ ) and actin (Fig. 1B,E,H) staining. The changes in phosphotyrosine staining that occurred in $3 \mathrm{~T} 3$ fibroblasts upon 24-hour serum-depletion, and following stimulation with $0.5 \%$ FBS for 30 minutes were similar to the changes in vinculin distribution. Phosphotyrosine was very prominent in the focal adhesions of the control, confluent fibroblasts (Fig. 1C). Upon serum-starvation the amount of phosphotyrosine staining in focal adhesions was greatly reduced (Fig. $1 \mathrm{~F}$ ), and the number of focal adhesions decreased. These changes in focal adhesion staining were accompanied by a reduction in number and size of stress fibers (Fig. 1E). In addition, remaining bundles of actin filaments had an unusual morphology, which was mostly peripheral. Stimulation of the cells with $0.5 \%$ FBS induced rapid changes in the appearance of the actin cytoskeleton. Within 30 minutes phosphotyrosine staining in focal adhesions greatly increased (Fig. 1I). There was an increase in the number of focal adhesions, that stained positively for both vinculin (Fig. 1G) and phosphotyrosine (Fig. 1H). The focal adhesions were large, elongated and could be found both at the cell periphery and more centrally (Fig. 1G,I). These focal adhesions were accompanied by new stress fibers (Fig. 1H), which often appeared to cover much of the ventral surface of the cell. We also examined whether there was a reorganization of ECM components, such as fibronectin, in parallel with the cytoskeletal rearrangements. Staining for fibronectin revealed no detectable difference between the starved and the serum- or LPA-stimulated cells (data not shown).

Since FAK tyrosine phosphorylation has been observed during formation of new focal adhesions in cells adhering to ECM (Burridge et al., 1992b; Guan and Shalloway, 1992;
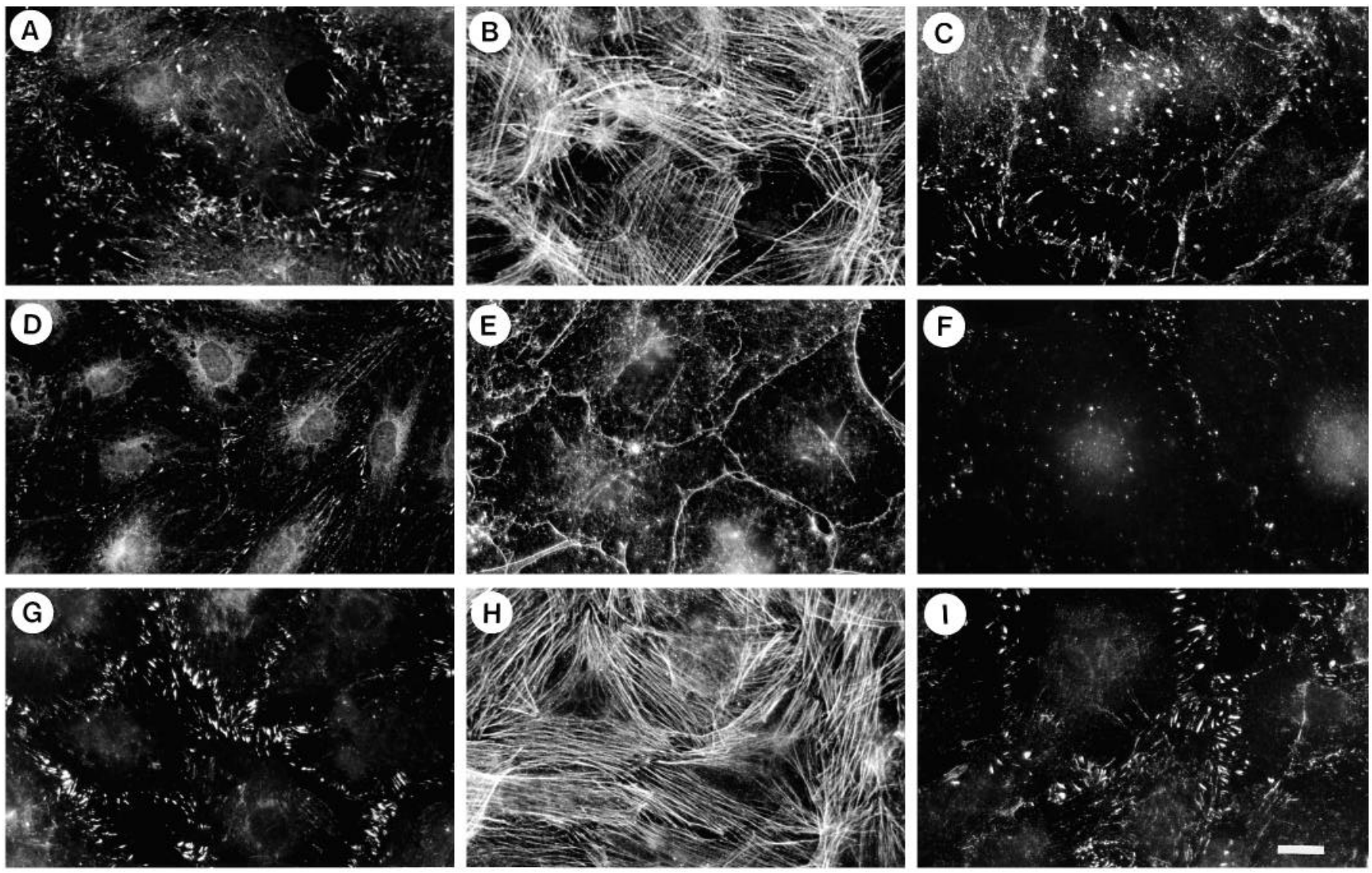

Fig. 1. Vinculin, actin and phosphotyrosine immunolocalization in quiescent $3 T 3$ fibroblasts stimulated with serum. 3T3 cells were grown 7-10 days past confluence in $10 \%$ BCS, without feeding (A,B,C), then cells were serum-starved for 24 hours (D,E,F) and stimulated with $0.5 \%$ FBS for 30 minutes $(\mathrm{G}, \mathrm{H}, \mathrm{I})$. Cells were fixed, permeabilized and stained with anti-vinculin antibody $(A, D, G)$, fluorescent phalloidin (for actin) $(\mathrm{B}, \mathrm{E}, \mathrm{H})$ and anti-phosphotyrosine antibody $(\mathrm{C}, \mathrm{F}, \mathrm{I})$. Bar, $20 \mu \mathrm{m}$. 


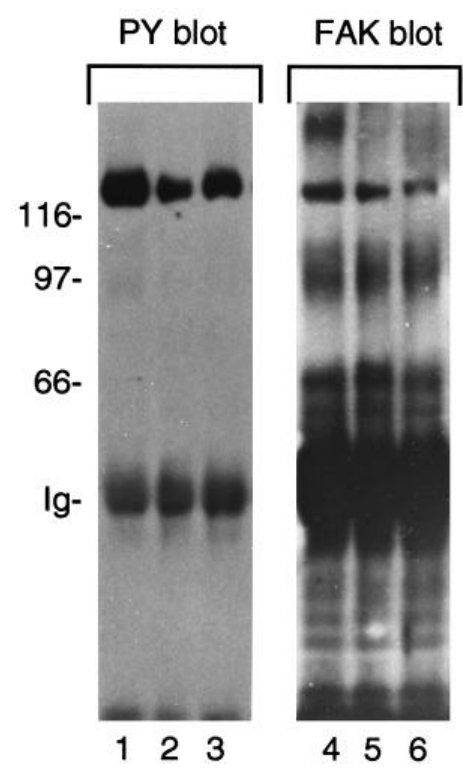

Fig. 2. Serum stimulates tyrosine phosphorylation of FAK. FAK was immunoprecipitated from Swiss 3 T3 fibroblasts that were grown 7-10 days past confluence in $10 \%$ BCS (lanes 1 and 4), and starved in the absence of serum for 24 hours (lanes 2 and 5) and then stimulated with $0.5 \%$ FBS for 30 minutes (lanes 3 and 6). The blot was first probed with antiphosphotyrosine antibody (left panel, lanes 1-3), then stripped and reprobed with anti-FAK antibody (right panel, lanes 4-6). The

molecular masses of marker proteins are indicated in kilodaltons and Ig indicates immunoglobulins.

Hanks et al., 1992; Kornberg et al., 1992; Romer et al., 1992, 1994), we examined FAK phosphorylation in serum-stimu- lated, quiescent Swiss 3T3 fibroblasts. Immunoprecipitated FAK was heavily phosphorylated on tyrosine in confluent Swiss 3T3 fibroblasts grown in 10\% BCS (Fig. 2, lane 1). Serum-starvation caused a decrease in FAK tyrosine phosphorylation (Fig. 2, lane 2). FAK phosphorylation increased upon stimulation with $0.5 \%$ FBS (Fig. 2, lane 3).

We have found here that the changes in the phosphotyrosine staining upon starvation and following serum treatment are similar to the changes in vinculin staining under the same conditions (as shown here and reported previously (Ridley and Hall, 1992)). Increased phosphorylation of FAK parallels and may be associated with the elevated phosphotyrosine staining in focal adhesions of stimulated cells.

\section{Inhibition of cytosolic phosphatases mimics effects of serum on Swiss 3T3 fibroblasts}

Sodium orthovanadate in conjunction with hydrogen peroxide (pervanadate) acts as a potent inhibitor of a variety of cellular phosphatases in vivo (Heffetz et al., 1990; Bushkin et al., 1991; Volberg et al., 1991). Volberg and colleagues have shown that pervanadate treatment of MDCK cells causes rapid formation of focal adhesions (Volberg et al., 1992). In addition, increased tyrosine phosphatase activity has been associated with cell detachment from the substratum and focal adhesion disassembly (Maher, 1993). To examine the effects of tyrosine phosphatase inhibition on the organization of the cytoskeleton in
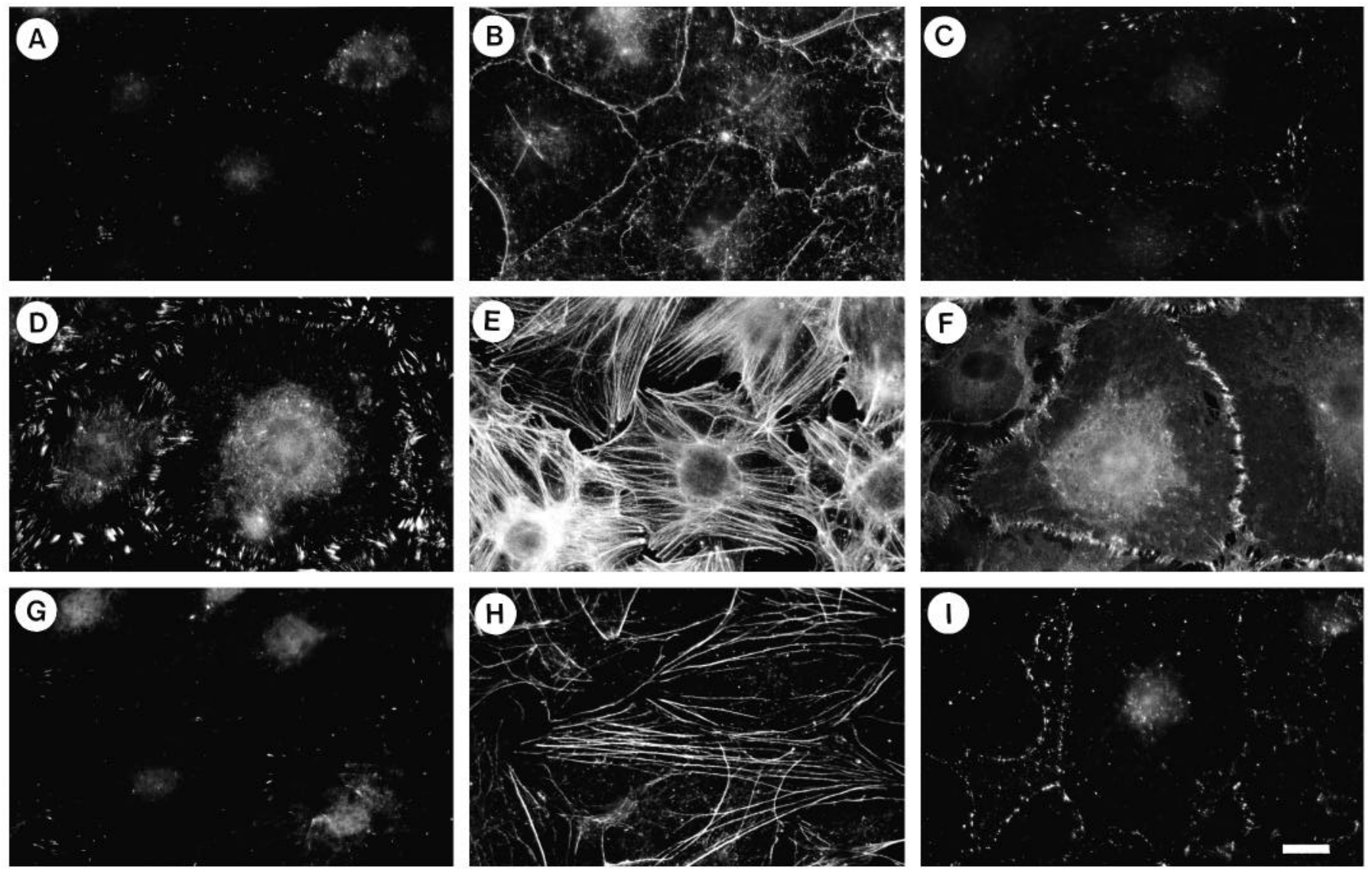

Fig. 3. Pervanadate, but not phenylarsine oxide, mimics the effect of serum on the actin cytoskeleton in quiescent 3 T3 fibroblasts. Quiescent fibroblasts, starved for 24 hours $(\mathrm{A}, \mathrm{B}, \mathrm{C})$, were incubated with $1 \mathrm{mM}$ sodium orthovanadate and $3 \mathrm{mM}$ hydrogen peroxide $(\mathrm{D}, \mathrm{E}, \mathrm{F})$ or $50 \mu \mathrm{M}$ phenylarsine oxide $(\mathrm{G}, \mathrm{H}, \mathrm{I})$ in serum-free media for 20 minutes. Cells were fixed, permeabilized and stained for vinculin $(\mathrm{A}, \mathrm{D}, \mathrm{G})$, actin $(\mathrm{B}, \mathrm{E}, \mathrm{H})$ or phosphotyrosine (C,F,I), as described in Fig. 1. Bar, $20 \mu \mathrm{m}$. 
A.

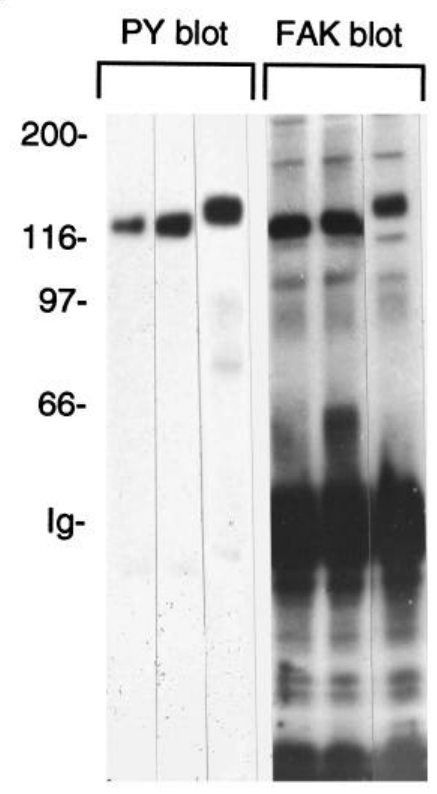

$\begin{array}{llllll}1 & 2 & 3 & 4 & 5 & 6\end{array}$
B.

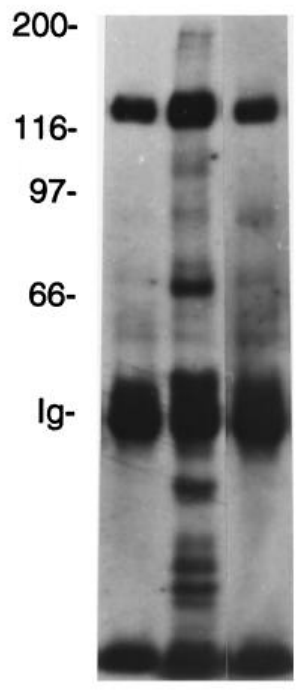

123

Fig. 4. Pervanadate but not phenylarsine oxide stimulates tyrosine phosphorylation of FAK. 3T3 cells were grown in 10\% BCS for 7-10 days past confluence, starved for 24 hours in serum-free media (A and $\mathrm{B}$, lane 1) and stimulated with serum (A and $\mathrm{B}$, lane 2) or $1 \mathrm{mM}$ sodium orthovanadate and $3 \mathrm{mM}$ hydrogen peroxide (A, lane 3 ) or $50 \mu \mathrm{M}$ phenylarsine oxide (B, lane 3 ) in serum-free media. Cell lysates were immunoprecipitated with anti-FAK antibody and probed with anti-phosphotyrosine. The blot was stripped and reprobed with anti-FAK antibody to confirm that equal amounts of the immunoprecipitated protein were present in each lane (A, lanes 4-6 correspond to lanes 1-3, and data not shown).

quiescent Swiss 3 T3 fibroblasts, we tested $1 \mathrm{mM}$ sodium orthovanadate with $3 \mathrm{mM}$ hydrogen peroxide (Fig. 3). Very abundant and prominent stress fibers formed across the ventral cell surface (Fig. 3E) within 10 minutes of treatment. These new stress fibers were anchored in large, well developed focal adhesions (Fig. 3D). Phosphotyrosine staining in pervanadate treated cells was most intense at the peripheral focal adhesions, but was present at a high level throughout the cytoplasm (Fig. $3 \mathrm{~F})$.

The elevation in phosphotyrosine staining induced by pervanadate treatment of quiescent fibroblasts (Fig. 3) correlated with an elevation in FAK phosphorylation (Fig. 4, lane 3) to a level similar to that of serum-stimulated cells (Fig. 4A, lane 2). A marked shift in the mobility of FAK was observed in cells treated with pervanadate (Fig. 4A, lanes 3 and 6). Since FAK with equivalent levels of tyrosine phosphorylation (Fig. 4A, lane 2) did not reveal this shift in mobility, we suspect that it was most likely due to additional phosphorylation on serine and/or threonine residues. Similar shifts in mobility have been noted for other proteins upon phosphorylation, such as MAP kinase (Boulton and Cobb, 1991). Phenylarsine oxide, a tyrosine phosphatase inhibitor specific for the membrane-associated phosphatases (Garcia-Morales et al., 1990; Liao et al., 1991), neither stimulated the formation of focal adhesions and

stress fibers (Fig. 3G,H,I), nor induced FAK tyrosine phosphorylation (Fig. 4B, lane 3).

These data support the idea that the observed changes in the cytoskeleton of Swiss 3T3 fibroblasts are related to levels of tyrosine phosphorylation. Increasing tyrosine phosphorylation with some tyrosine phosphatase inhibitors led to the formation of stress fibers and focal adhesions.

\section{Involvement of kinases in the formation of stress fibers and focal adhesions}

The increased tyrosine phosphorylation of FAK observed upon serum-stimulation, could result from tyrosine kinase activation, or tyrosine phosphatase inhibition. To investigate the possibility of a tyrosine kinase involvement, we used two different tyrosine kinase inhibitors during serum-stimulation of quiescent fibroblasts. Erbstatin analog (EA) (Umezawa et al., 1986; Imoto et al., 1987; Isshiki et al., 1987) inhibited serum induction of focal adhesions (Fig. 5G,I), and stress fibers (Fig. 5H). This response to EA was dose-dependent (data not shown). Furthermore, EA decreased FAK phosphorylation below the level of serum-starved cells (Fig. 6, lanes 3,4).

Genistein (4',5,7-trihydroxyisoflavone) competitively inhibits ATP binding to the kinase domain of several tyrosine kinases (Akiyama et al., 1987; Linassier et al., 1989). The presence of genistein at $100 \mu \mathrm{g} / \mathrm{ml}$ and above (for higher concentrations the data are not shown) completely inhibited the formation of focal adhesions (Fig. 5J,L), and prevented the increase in number of stress fibers (Fig. 5K) in fibroblasts stimulated with $0.5 \%$ FBS (compare to $0.5 \%$ FBS alone in Fig. $5 \mathrm{D}, \mathrm{E}, \mathrm{F})$. FAK precipitates from fibroblasts stimulated with $0.5 \% \mathrm{FBS}$ in the presence of genistein showed lower levels of tyrosine phosphorylation (Fig. 6, lanes 5,6) than seen in precipitates from serum-starved cells (Fig. 6, lane 1).

The ability of the kinase inhibitors, EA and genistein, to prevent serum-induced changes in the cytoskeleton and corresponding changes in FAK phosphorylation, indicates that one or more kinases are involved in the observed effects of serum.

\section{Some tyrosine kinase inhibitors block cytoskeletal response to LPA, but not serum}

Lysophosphatidic acid (LPA) is a lipid in serum that stimulates the reappearance of the stress fibers and focal adhesions in quiescent Swiss 3T3 fibroblasts (Ridley and Hall, 1992). Fig. 7 shows the effect of LPA on quiescent Swiss 3T3 cells. LPA at $200 \mathrm{ng} / \mathrm{ml}$ induced vinculin (Fig. 7G) and phosphotyrosine (Fig. 7I) staining in focal adhesions to the level seen in $0.5 \%$ FBS-stimulated fibroblasts (Fig. 7D,F). Like serum (Fig. 7E), LPA induced the formation of many new stress fibers (Fig. 7H). LPA treatment caused increased tyrosine phosphorylation of FAK (Fig. 9, lane 3) to a level similar to that with serum (Fig. 9, lane 2). A similar increase in tyrosine phosphorylation of FAK in response to LPA has been reported by others (Kumagai et al., 1993; Seufferlein and Rozengurt, 1994). The increase in tyrosine phosphorylation of FAK upon 5-minute treatment with $0.5 \%$ serum or $2 \mu \mathrm{g} / \mathrm{ml}$ LPA was determined by ${ }^{35} \mathrm{~S}$-metabolic labeling and immunoprecipitation of FAK with anti-phosphotyrosine and anti-FAK antibodies. Under these conditions there was an increase in FAK tyrosine phosphorylation of approximately $70 \%$.

These effects of LPA can be inhibited by a subset of tyrphostins. Tyrphostin 47 (AG 213) and tyrphostin 25 (3,4,5-tri- 

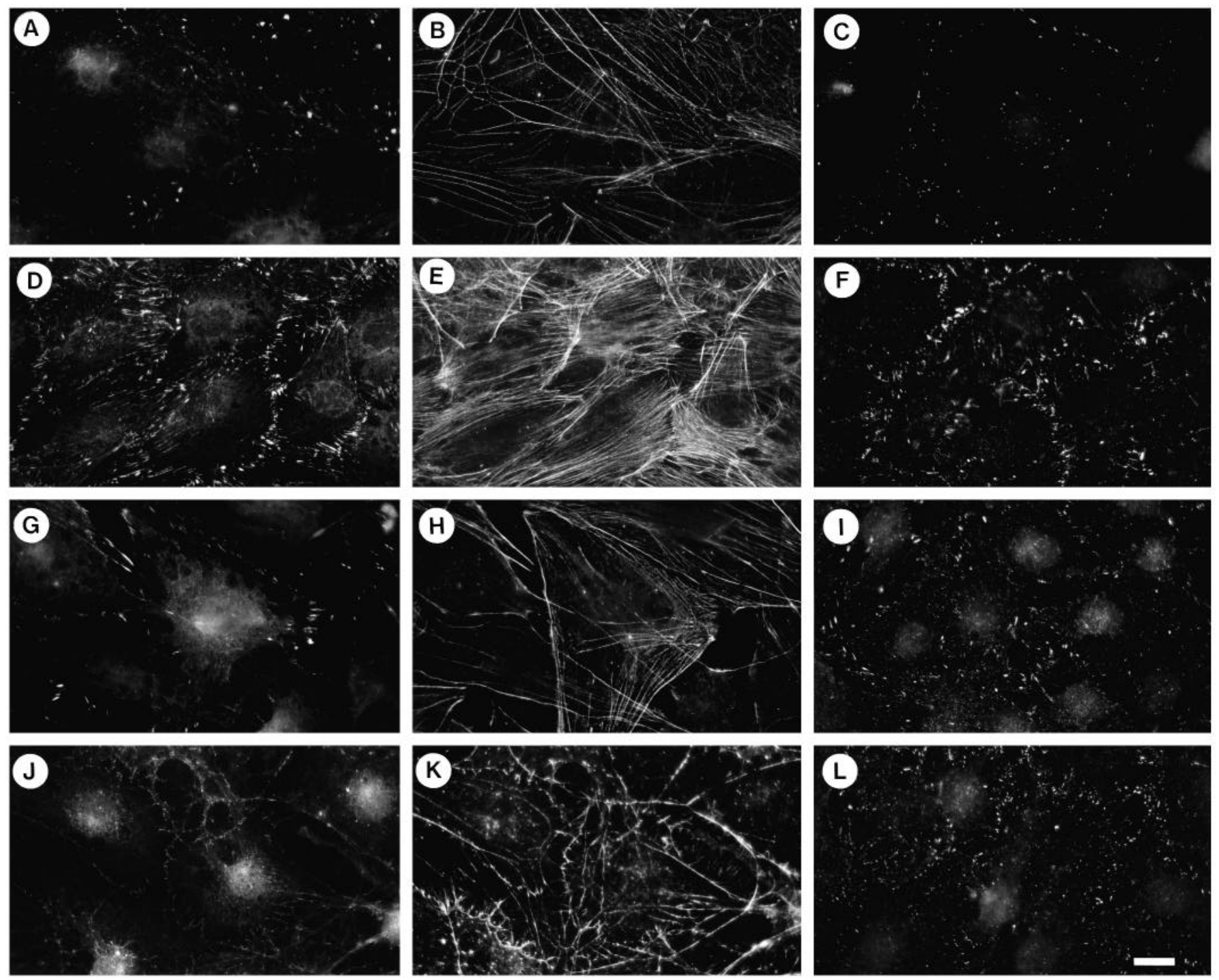

Fig. 5. Tyrosine kinase inhibitors, erbstatin analog and genistein, block the cytoskeletal response to serum. Serum-starved 3 T3 cells (A,B,C) were stimulated for 30 minutes either with $0.5 \%$ FBS alone (D,E,F) or serum to which either $10 \mu \mathrm{g} / \mathrm{ml}$ erbstatin analog $(\mathrm{G}, \mathrm{H}, \mathrm{I})$ or $50 \mu \mathrm{g} / \mathrm{ml}$ genistein $(\mathrm{J}, \mathrm{K}, \mathrm{L})$ were added. Erbstatin analog was present in the incubation media during the last 1 hour of starvation and during stimulation. Genistein was in the incubation media for the last 3 hours of starvation and during stimulation. Cells were stained for vinculin (A,D,G,J), actin (B,E,H,K) or phosphotyrosine (C,F,I,L). Bar, $20 \mu \mathrm{M}$.

hydroxy cis-cinnamonitrile) have been used to inhibit FAK phosphorylation in response to adhesion (Romer et al., 1994) and bombesin stimulation (Seckl and Rozengurt, 1993). The addition of $120 \mu \mathrm{M}$ tyrphostin 47 during serum-starvation and LPA stimulation abolished the effect of LPA on the cytoskeleton by inhibiting the reappearance of focal adhesions (Fig. 8E) and stress fibers (Fig. 8F). Similar results were obtained with tyrphostin 25 (data not shown). Decreased phosphorylation of FAK accompanied the inhibition of cytoskeletal reorganization. Treatment of starved 3T3 fibroblasts with LPA and tyrphostin 47 (Fig. 9, lane 7), or tyrphostin 25 (Fig. 9, lane 8) resulted in the complete inhibition of FAK phosphorylation, compared to LPA alone (Fig. 9, lane 4). However, when tyrphostins 47 and 25 were used with $0.5 \%$ FBS only small inhibition of FAK phosphorylation was observed (Fig. 9, lane 6, and data not shown ). Additionally, neither tyrphostin seemed to have a major effect on the cytoskeletal response to serum (Fig. 8C,D and data not shown).

\section{LPA signaling and the reappearance of the actin cytoskeleton}

LPA signaling involves two separate pathways: the activation of PLC coupled to a PTX-insensitive G protein and the activation of a pertussis toxin (PTX)-sensitive $\mathrm{G}$ protein leading to activation of p21ras, MAPK and accumulation of cAMP (van Corven et al., 1993). To elucidate which of the pathways is connected to the cytoskeletal changes observed upon LPA stimulation, we studied the effects of PTX (Fig. 10) and a PLC inhibitor, the aminosteroid U-73122 (Bleasdale et al., 1990; Smith et al., 1990) (Fig. 11) during the stimulation of quiescent cells with LPA. We found that up to $500 \mathrm{ng} / \mathrm{ml}$ PTX had no effect on stimulated cells (Fig. 10E,F). In contrast, U-73122, a 


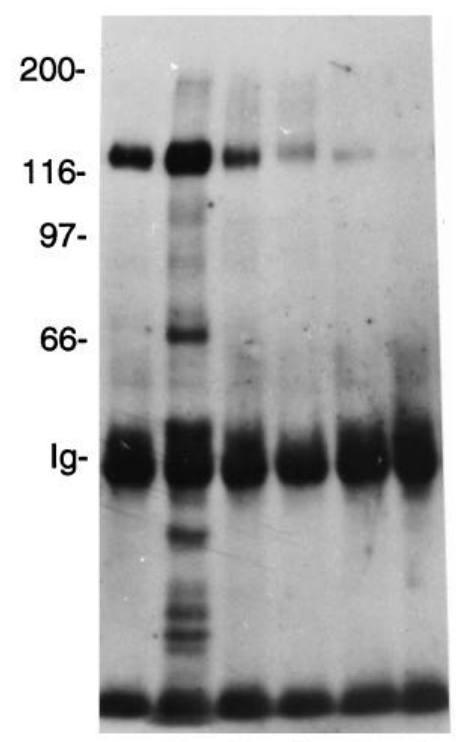

$\begin{array}{llllll}1 & 2 & 3 & 4 & 5 & 6\end{array}$
Fig. 6. Erbstatin analog and genistein inhibit seruminduced tyrosine phosphorylation of FAK. FAK was

immunoprecipitated from serum-starved cells (lane 1), that were then stimulated with either $0.5 \%$ FBS alone (lane 2), or with the addition of tyrosine kinase inhibitors. Erbstatin analog was added at $15 \mu \mathrm{g} / \mathrm{ml}$ (lane 3) or 50 $\mu \mathrm{g} / \mathrm{ml}$ (lane 4); genistein was used at $100 \mu \mathrm{g} / \mathrm{ml}$ (lane 5) or $250 \mu \mathrm{g} / \mathrm{ml}$ (lane 6). Erbstatin analog was present in the incubation media during the last 1 hour of starvation and during serum-stimulation.

Genistein was added 3 hours prior to and during stimulation. The blot was probed with anti-phosphotyrosine and then stripped and reprobed with anti-FAK to ensure equal protein loading (data not shown).

PLC inhibitor, blocked the reformation of stress fibers and focal adhesions in response to treatment with LPA (Fig.
$11 \mathrm{E}, \mathrm{F})$. In addition, cell morphology was affected, the cells appeared to be retracted, indicating decreased adhesion and/or increased contractility. The inactive analog of the inhibitor, U73343, had no effect on the response to LPA (Fig. 11G,H). These results indicate that activation of PLC is involved in the cytoskeletal rearrangements induced by LPA. Previous work has demonstrated the tyrosine phosphorylation of proteins including FAK following PLC activation (Hordijk et al., 1994). Together these data argue that cytoskeletal regulation by LPA occurs via the PLC signaling pathway rather than the PTXsensitive G-protein pathway.

\section{DISCUSSION}

Cell adhesion to ECM is associated with the tyrosine phosphorylation of a small set of proteins (Guan et al., 1991; Burridge et al., 1992b; Kornberg et al., 1992; Romer et al., 1992; Bockholt and Burridge, 1993). This tyrosine phosphorylation has been implicated in the assembly of focal adhesions and stress fibers as cells spread on an ECM substratum. Not only is the focal adhesion kinase, FAK, one of the proteins that becomes phosphorylated in response to adhesion (Burridge et al., 1992b; Guan and Shalloway, 1992; Hanks et al., 1992; Kornberg et al., 1992; Pelletier, 1992; Romer et al., 1992), but its activity is also stimulated (Guan and Shalloway, 1992; Lipfert et al., 1992; Romer et al., 1994). In addition, inhibition
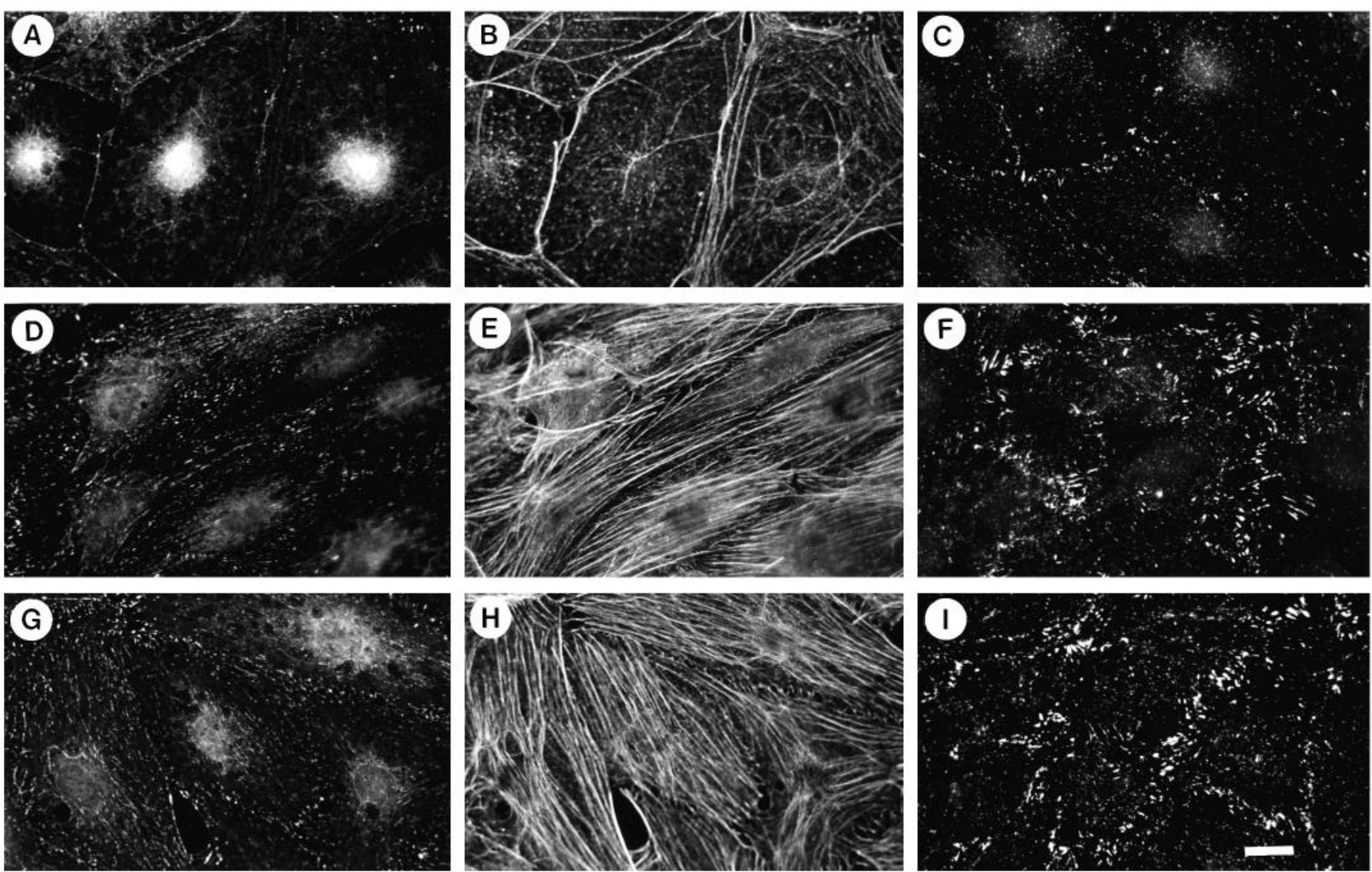

Fig. 7. Lysophosphatidic acid stimulates reorganization of the actin cytoskeleton. Quiescent, starved $3 \mathrm{~T} 3$ cells $(\mathrm{A}, \mathrm{B}, \mathrm{C})$ were stimulated for 30 minutes either with $0.5 \% \mathrm{FBS}(\mathrm{D}, \mathrm{E}, \mathrm{F})$ or $200 \mathrm{ng} / \mathrm{ml} \mathrm{LPA}(\mathrm{G}, \mathrm{H}, \mathrm{I})$. Cells were stained for vinculin $(\mathrm{A}, \mathrm{D}, \mathrm{G})$, actin $(\mathrm{B}, \mathrm{E}, \mathrm{H})$ or phosphotyrosine (C,F,I). Bar, $20 \mu \mathrm{m}$. 

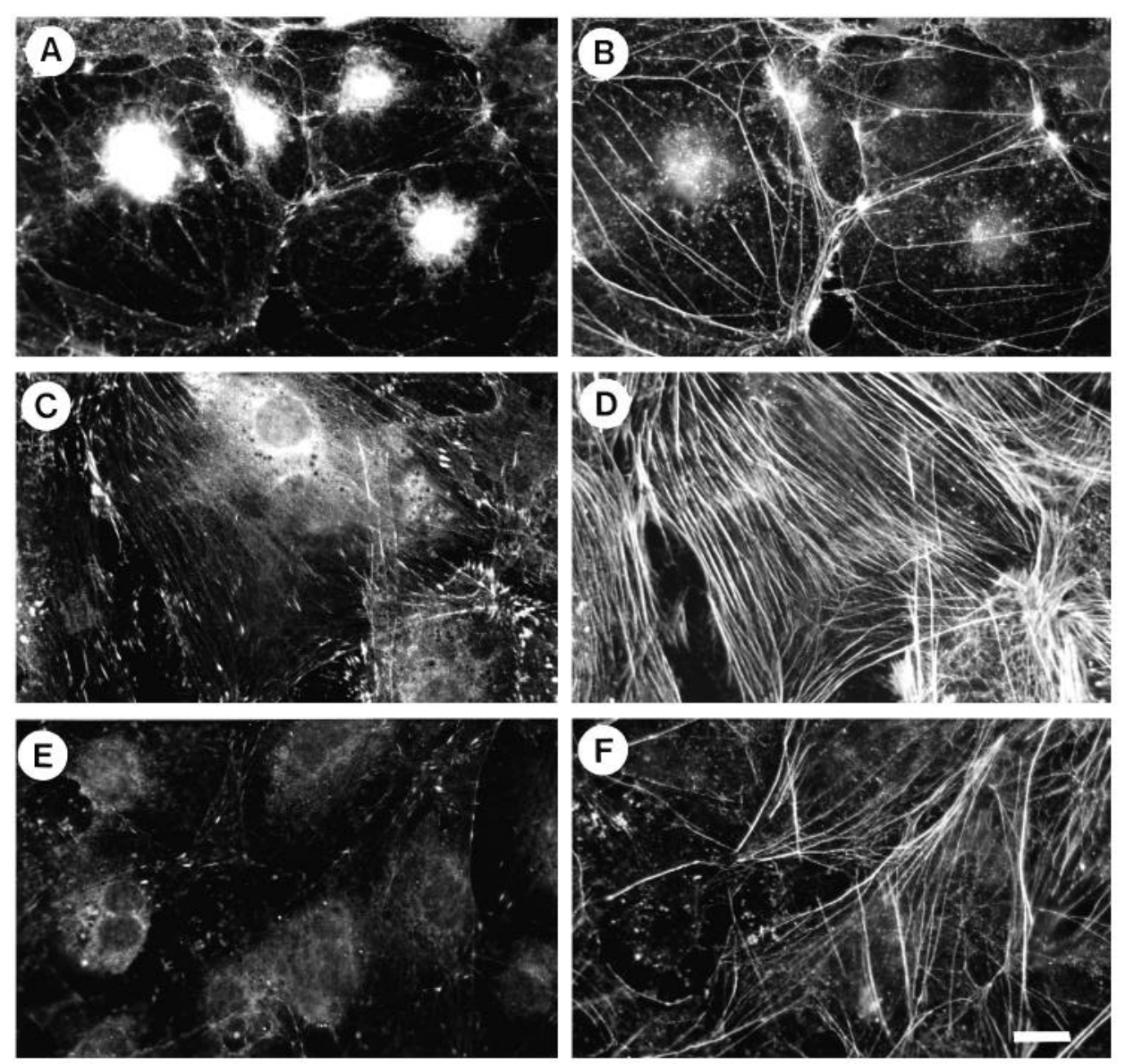

Fig. 8. Tyrphostin 47 inhibits LPAinduced actin reorganization.

Tyrphostin 47 at $120 \mu \mathrm{M}$ was present in the incubation media during 24 hours of starvation $(\mathrm{A}, \mathrm{B})$ and during a 30 minute stimulation with either $0.5 \%$ FBS (C,D) or $200 \mathrm{ng} / \mathrm{ml}$ LPA (E,F). Cells were stained for vinculin $(\mathrm{A}, \mathrm{C}, \mathrm{E})$ or actin (B,D,F). Bar, $20 \mu \mathrm{m}$. of FAK by herbimycin A and tyrphostins prevents the formation of focal adhesions (Burridge et al., 1992; Romer et al., 1992, 1994).

Here we have used another model system for studying the formation of stress fibers and focal adhesions in starved and quiescent fibroblasts (Rozengurt and Sinnett-Smith, 1983; Ridley and Hall, 1992). Rho A can be activated by serum, LPA, and to a lesser extent some growth factors, resulting in the rapid assembly of focal adhesions and stress fibers (Ridley and Hall, 1992). In this paper we demonstrate that FAK becomes tyrosine phosphorylated as the formation of new stress fibers and focal adhesions is induced by serum or LPA treatment.

In order to establish whether tyrosine phosphorylation is the cause or the result of the formation of the new cytoskeletal structures, we have attempted either to promote intracellular tyrosine phosphorylation by using tyrosine phosphatase inhibitors, or to decrease the level of tyrosine phosphorylation by using tyrosine kinase inhibitors. We have found that pervanadate treatment of starved, quiescent Swiss 3T3 cells rapidly induces the formation of focal adhesions and stress fibers. A concomitant increase in the tyrosine phosphorylation of FAK has also been observed. Pervanadate is a broad spectrum tyrosine phosphatase inhibitor and elevated the level of phosphotyrosine in many proteins (data not shown). It is of interest that previous work has shown that pervanadate stimulates the formation of focal adhesions in MDCK cells, while at the same time promoting the disassembly of the cell-cell

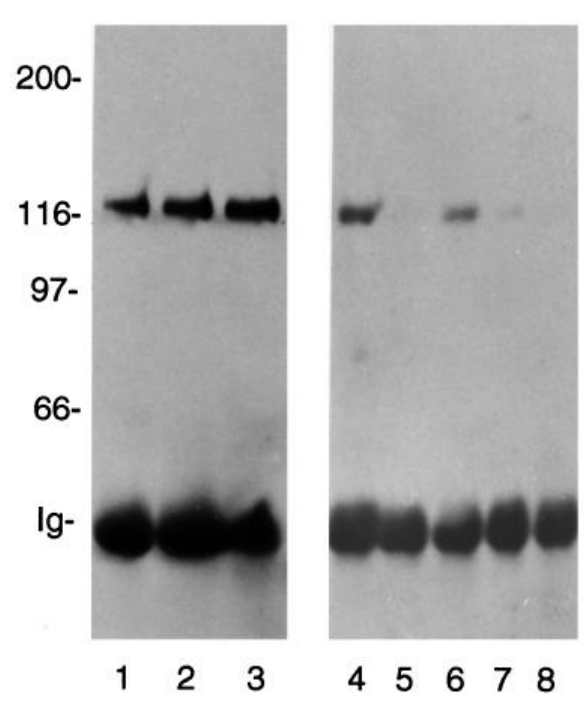

Fig. 9. Tyrphostins inhibit LPA-induced FAK phosphorylation. FAK was immunoprecipitated from starved cells (lane 1), cells stimulated with either $0.5 \%$ FBS for 5 minutes (lane 2) or $200 \mathrm{ng} / \mathrm{ml} \mathrm{LPA} \mathrm{(5}$ minutes, lane 3 and 30 minutes, lane 4). Tyrphostin 47 at $120 \mu \mathrm{M}$ was present during serum-starvation (lane 5) and following 30minute stimulation with $0.5 \%$ FBS (lane 6) or $200 \mathrm{ng} / \mathrm{ml}$ LPA (lane $7)$. In lane 8 , the conditions were as in lane 7 , but tyrphostin 25 was used instead of tyrphostin 47 . The blot was probed with antiphosphotyrosine. 

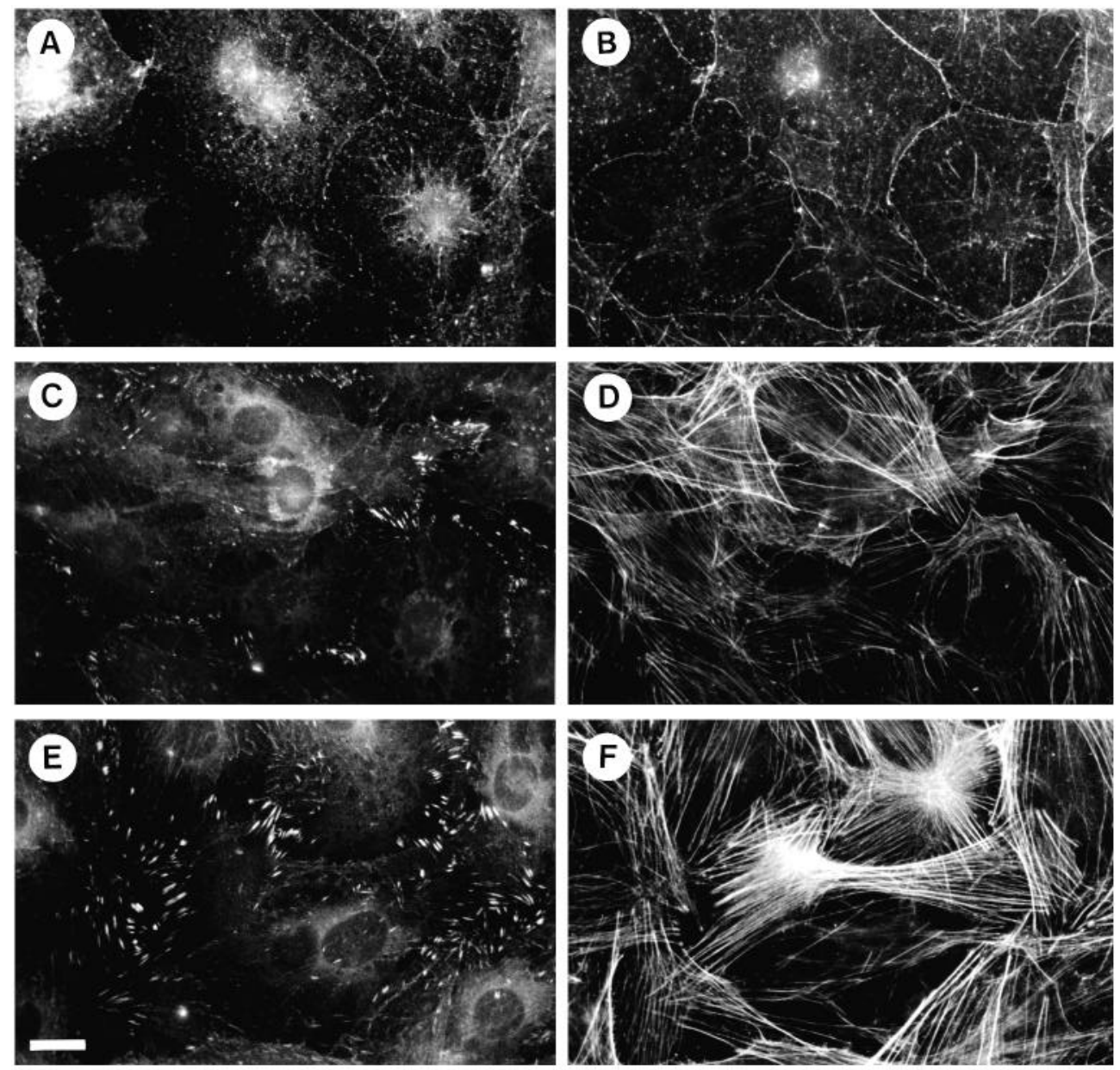

Fig. 10. PTX does not affect LPAinduced actin reorganization. Quiescent, starved 3T3 cells (A,B) were stimulated for 30 minutes either with $200 \mathrm{ng} / \mathrm{ml}$ LPA alone (C,D) or LPA with $500 \mathrm{ng} / \mathrm{ml}$ PTX (E,F). Cells were stained for vinculin $(\mathrm{A}, \mathrm{C}, \mathrm{E})$ or actin $(\mathrm{B}, \mathrm{D}, \mathrm{F})$. Bar, $20 \mu \mathrm{m}$.

junctions in these cells (Volberg et al., 1992). Phenylarsine oxide is a protein tyrosine phosphatase inhibitor with a narrower specificity than pervanadate, inhibiting primarily membrane-associated protein tyrosine phosphatases (GarciaMorales et al., 1990; Liao et al., 1991). In quiescent 3T3 cells, phenylarsine oxide did not stimulate tyrosine phosphorylation of FAK, nor did it promote the assembly of stress fibers and focal adhesions.

Two tyrosine kinase inhibitors (genistein and EA), had the opposite effect of pervanadate. These inhibitors blocked both the tyrosine phosphorylation of FAK and the reappearance of stress fibers and focal adhesions in response to serum stimulation. These results support the idea that FAK tyrosine phosphorylation and, by implication, FAK activity have a role in the assembly of focal adhesions and stress fibers. However, these inhibitors suffer the disadvantage of having broad specificities. Genistein is a competitive inhibitor of the ATP binding site, which is a conserved structural feature in all protein kinases. It also non-competitively inhibits phosphor acceptor substrate binding to protein kinases. Accordingly, genistein has been shown to inhibit some serine/threonine kinases (Akiyama et al., 1987; Linassier et al., 1989). Erbstatin and its analog (EA) structurally mimic the tyrosyl moiety and thus show more specificity towards tyrosine kinases. The erbstatin analog we used (Umezawa et al., 1989) retains the inhibitory activity of erbstatin and has an advantage over erbstatin by being more stable in serum and having reduced polarity, which facilitates membrane penetration. Both of these inhibitors non-competitively inhibit ATP binding (Umezawa et al., 1986; Imoto et al., 1987; Isshiki et al., 1987), and hence at higher concentrations can inhibit serine/threonine kinases (Bishop et al., 1990; Salari et al., 1990). For these reasons we turned to explore the effects of various tyrphostins.

Tyrphostins are a family of inhibitors designed to bind competitively to the phosphor acceptor site in the kinase domain of tyrosine kinases (Yaish et al., 1988; Gazit et al., 1989). These are tyrosine kinase specific and do not inhibit PKA, PKC or other serine/threonine kinases (Levitzki, 1990). Tyrphostins have ben used to inhibit FAK phosphorylation in response to cell adhesion and migration (tyrphostin 47) (Romer et al., 1994), as well as bombesin stimulation (tyrphostin 25) (Seckl and Rozengurt, 1993). However, in the current work, neither tyrphostin was found to completely prevent FAK phosphorylation or the induction of focal adhesions and stress fibers in response to serum stimulation of quiescent cells. This finding was surprising, since tyrphostins have been effective at inhibiting FAK previously (Romer et al., 1994; Seckl and Rozengurt, 1993), and inhibited FAK phosphorylation in this study when LPA was used as a stimulus. One possible explanation is that serum stimulates the reappearance of stress fibers and focal adhesions by an additional pathway, distinct from LPA and FAK activation. An unidentified kinase in this pathway could be responsible for phosphorylating FAK. The activity of this kinase would be inhibited by erbstatin and genistein, broad 

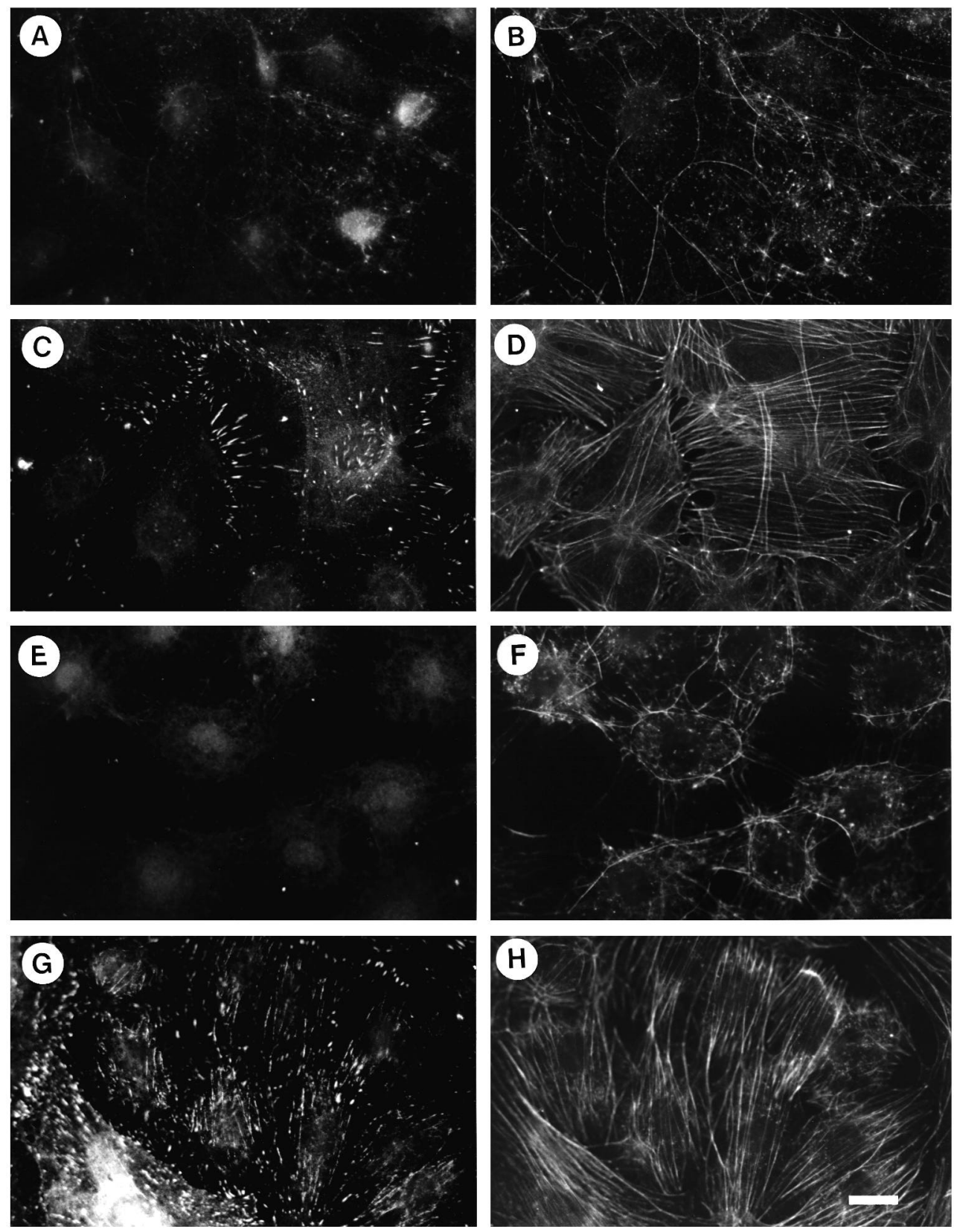

Fig. 11. PLC is involved in LPAinduced actin reorganization. Quiescent, starved 3T3 cells (A,B) were stimulated for 30 minutes either with $200 \mathrm{ng} / \mathrm{ml}$ LPA alone (C,D) or LPA with PLC inhibitor, U-73122 (E,F) or LPA with an inactive form of the inhibitor, $\mathrm{U}$ $73343(\mathrm{G}, \mathrm{H})$. Vinculin (A,C,E,G) and actin $(\mathrm{B}, \mathrm{D}, \mathrm{F}, \mathrm{H})$ are visualized. Bar, $20 \mu \mathrm{m}$. spectrum kinase inhibitors, but not by the tyrphostins used in this study. These tyrphostins could prevent the autophosphorylation of FAK, but not its phosphorylation by this other kinase. Future work will be needed to determine whether another kinase is involved in the cytoskeletal response to serum.

At present, the signaling pathway leading from LPA to the formation of stress fibers and focal adhesions, is not well understood. LPA is known to act via a membrane receptor, coupled to two distinct $\mathrm{G}$ protein-linked pathways (Hordijk et al., 1994). One, starting at a pertussis toxin-sensitive heterotrimeric $G_{i}$ protein, leads through an unidentified kinase to the activation of p21 ras (van Corven et al., 1993) and MAP kinase (Hordijk et al., 1994). Independent of this mitogenic pathway, another $\mathrm{G}$ protein (pertussis toxin-insensitive) couples the LPA receptor to PLC activation (van Corven et al.,
1989; Plevin et al., 1991). The PLC pathway was also suggested to lead to the phosphorylation of several proteins, including FAK (Hordijk et al., 1994, see also review by Moolenaar, 1994). Consistent with this theory, we found that an inhibitor of PLC, but not pertussis toxin, blocked the response of cells to LPA.

LPA also leads to the activation of RhoA (Ridley and Hall, 1992) and this is required for the formation of focal adhesions and stress fibers. The mechanism of RhoA activation by LPA is not known. However, it has been shown that inhibition of RhoA by Clostridium botulinum C3 exotransferase inhibits LPA-induced FAK phosphorylation (Kumagai et al., 1993). This suggests that RhoA acts upstream of FAK. It will be important to determine how RhoA activates FAK, whether this is the result of a direct interaction or whether there are multiple steps between these two regulatory proteins. 
We thank Susanne Bockholt for her generous help with immunoprecipitations and photography, Dr Lewis Romer for his valuable advice on the use of inhibitors, Dr Michael Kinch and all our colleagues who contributed to this paper by critical reading of the manuscript and helpful discussions. This work was supported by NIH Grants: HL45100 and GM29860.

\section{REFERENCES}

Akiyama, T., Ishida, J., Nakagawa, S., Ogawara, H., Watanabe, S., Itoh, N., Shibuya, M. and Fukami, Y. (1987). Genistein, a specific inhibitor of tyrosine-specific protein kinases. J. Biol. Chem. 262, 5592-5595.

Bishop, W. R., Petrin, J., Wang, L., Ramesh, U. and Doll, R. J. (1990). Inhibition of protein kinase $\mathrm{C}$ by the tyrosine kinase inhibitor erbstatin Biochem. Pharmacol. 40, 2129-2135.

Bleasdale, J. E., Thakur, N. R., Gremban, R. S., Bundy, G. L., Fitzpatrick, F. A., Smith, R. J. and Bunting, S. (1990). Selective inhibition of receptorcoupled phospholipase C-dependent processes in human platelets and polymorphonuclear neutrophils. J. Pharmacol. Exp. Ther. 255, 756-768.

Bockholt, S. M. and Burridge, K. (1993). Cell spreading on extracellular matrix proteins induces tyrosine phosphorylation of tensin. J. Biol. Chem. 268, 14565-14567.

Bockholt, S. M. and Burridge, K. (1994). Focal adhesions and integrinmediated cell signaling. In The Cytoskeleton, vol. 2 (ed. J. E. Hesketh and I Pryme). Greenwich: JAI Press, Inc. (in press).

Boulton, T. G. and Cobb, M. H. (1991). Identification of multiple extracellular signal-regulated kinases (ERKs) with antipeptide antibodies. Cell Regul. 2, 357-371.

Burridge, K., Fath, K., Kelly, T., Nuckolls, G. and Turner, C. (1988). Transmembrane junctions between the extracellular matrix and the cytoskeleton. Annu. Rev. Cell Biol. 4, 487-525.

Burridge, K., Petch, L. A., and Romer, L. H. (1992a). Signaling in focal adhesions. Curr. Biol. 2, 537-539.

Burridge, K., Turner, C. E. and Romer, L. H. (1992b). Tyrosine phosphorylation of paxillin and pp125 $5^{\mathrm{FAK}}$ accompanies cell adhesion to extracellular matrix: a role in cytoskeletal assembly. J. Cell Biol. 119, 893903.

Bushkin, I., Roth, J., Heffetz, D. and Zick, Y. (1991). pp75: a novel tyrosinephosphorylated protein that heralds differentiation of HL-60 cells. J. Biol. Chem. 266, 11890-11895.

Chardin, P., Boquet, P., Maduale, P., Popoff, M. R., Rubin, E. J. and Gill, D. M. (1989). The mammalian G protein rhoC is ADP-ribosylated by Clostridium botulinum exoenzyme $\mathrm{C} 3$ and affects actin microfilaments in Vero cells. EMBO J. 8, 1087-1092.

Garcia-Morales, P., Minami, Y., Luong, E., Klausner, R. D. and Samelson, L. E. (1990). Tyrosine phosphorylation in T cells is regulated by phosphatase activity: studies with phenylarsine oxide. Proc. Nat. Acad. Sci. USA 87, 9255-9259.

Gazit, A., Yaish, P., Gilon, C. and Levitzki, A. (1989). Tyrphostins I: synthesis and biological activity of protein tyrosine kinase inhibitors. J. Med. Chem. 32, 2344-2352

Geiger, B. (1989).Cytoskeleton-associated cell contacts. Curr. Opin. Cell Biol. 1, 103-109.

Glukhova, M. A., Frid, M. G., Shekhonin, B. V., Balabanov, Y. V. and Koteliansky, V.E. (1990). Expression of fibronectin variants in vascular and visceral smooth muscle. Dev. Biol. 141, 193-202.

Guan, J.-L., Trevithick, J. E. and Hynes, R. O. (1991). Fibronectin/integrin interaction induces tyrosine phosphorylation of a $120 \mathrm{kDa}$ protein. Cell Regul. 2, 951-964.

Guan, J.-L. and Shalloway, D. (1992). Regulation of focal adhesionassociated protein tyrosine kinase by both cellular adhesion and oncogenic transformation. Nature 358, 690-692.

Hanks, S. K., Calalb, M. B., Harper, M. C. and Patel, S. K. (1992). Focal adhesion protein-tyrosine kinase phosphorylation in response to cell attachment to fibronectin. Proc. Nat. Acad. Sci. USA 89, 8487-8491.

Heffetz, D., Bushkin, I., Dror, R. and Zick, Y. (1990). The insulinomimetic agents $\mathrm{H}_{2} \mathrm{O}_{2}$ and vanadate stimulate protein tyrosine phosphorylation in intact cells. J. Biol. Chem. 265, 2896-2902.

Hordijk, P. L., Verlaan, I., van Corven, E. J. and Moolenaar, W. H. (1994). Protein tyrosine phosphorylation induced by lysophosphatidic acid in Rat-1 fibroblasts. Evidence that phosphorylation of MAP kinase is mediated by the

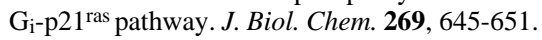

Hynes, R. O. (1992). Integrins: versatility, modulation, and signaling in cell adhesion. Cell 69, 11-25.

Imoto, M., Umezawa, H., Isshiki, K., Kunimoto, S., Sawa, T., Takeuchi, T. and Umezawa, H. (1987). Kinetic studies of tyrosine kinase inhibition by erbstatin. J. Antibiot. (Tokyo) 40, 1471-1473.

Isshiki, K., Imoto, M., Sawa, T., Umezawa, K., Takeuchi, T., Umezawa, H., Tsuchida, T., Yoshioka, T. and Tatsuta K. (1987). Inhibition of tyrosine protein kinase by synthetic erbstatin analogs. J. Antibiot. (Tokyo) 40, 1209 1210.

Juliano, R. L. and Haskill, S. (1993). Signal transduction from the extracellular matrix. J. Cell Biol. 120, 577-585.

Kornberg, L., Earp, H. S., Turner, C. E, Prockop, C. and Juliano, R. L. (1991). Signal transduction by integrins: increased protein tyrosine phosphorylation caused by clustering $\beta_{1}$ integrins. Proc. Nat. Acad. Sci. USA 88, 8392-8396.

Kornberg, L., Earp, H. S., Parsons, J. T., Schaller, M. and Juliano, R. L. (1992). Cell adhesion or integrin clustering increases phosphorylation of a focal adhesion-associated tyrosine kinase. J. Biol. Chem. 267, 2343923442.

Kumagai, N., Morii, N., Fujisawa, K., Nemoto, Y. and Narumiya, S. (1993). ADP-ribosylation of Rho p21 inhibits lysophosphatidic acid-induced protein tyrosine phosphorylation and phosphatidylinositol 3-kinase activation in cultured Swiss 3 T3 cells. J. Biol. Chem. 268, 24535-24538.

Laemmli, U. K. (1970). Cleavage of structural proteins during the assembly of the head of bacteriophage T4. Nature 227, 680-685.

Levitzki, A. (1990). Tyrphostins: potential antiproliferative agents and novel molecular tools. Biochem. Pharmacol. 40, 913-918.

Liao, K., Hoffman, R. D. and Lane, M. D. (1991). Phosphotyrosyl turnover in insulin signaling. Characterization of two membrane-bound pp15 tyrosine phosphatases from 3T3-L1 adipocytes. J. Biol. Chem. 266, 6544-6553.

Linassier, C., Pierre, M., Le Pecq, J.-B. and Pierre, J. (1989). Mechanisms of action in NIH-3T3 cells of genistein, an inhibitor of EGF receptor tyrosine kinase activity. Biochem. Pharmacol. 39, 187-193.

Lipfert, L., Haimovich, B., Shaller, M. D., Cobb, B. S., Parsons, J. T. and Brugge, J. (1992). Integrin-dependent phosphorylation and activation of the protein tyrosine kinase pp $125^{\mathrm{FAK}}$ in platelets. J. Cell Biol. 119, 905-912.

Maher, P. A. (1993). Activation of phosphotyrosine phosphatase activity by reduction of cell-substrate adhesion. Proc. Nat. Acad. Sci. USA 90, $11177-$ 11181.

Moolenaar, W. H. (1994). LPA: a novel lipid mediator with diverse biological actions. Trends Cell Biol. 4, 213-219.

Paterson, H. F., Self, A. J., Garrett, M. D., Just, I., Aktories, K. and Hall, A. (1990). Microinjection of recombinant $\mathrm{p} 21^{\text {rho }}$ induces rapid changes in cell morphology. J. Cell Biol. 111, 1001-1007.

Pelletier, A. J., Bodary, S. C. and Levinson, A. D. (1992). Signal transduction by the platelet integrin $\alpha_{\mathrm{II}} \beta_{\mathrm{III}}$ : induction of calcium ascillations required for protein-tyrosine phosphorylation and ligand-induced spreading of stably transfected cells. Mol. Biol. Cell 3, 989-998.

Plevin, R., MacNulty, E. E., Palmer, S. and Wakelam, M. (1991) Differences in the regulation of endothelin-1- and lysophosphatidic-acidstimulated Ins(1,4,3)P3 formation in Rat-1 fibroblasts. Biochem. J. 280, 609615.

Ridley, A. J. and Hall, A. (1992). The small GTP-binding protein rho regulates the assembly of focal adhesions and actin stress fibers in response to growth factors. Cell 70, 389-399.

Ridley, A. J., Paterson, H. F., Johnston, C. L., Diekman, D. and Hall, A. (1992). The small GTP-binding protein rac regulates growth factor-induced membrane ruffling. Cell 70, 401-410.

Romer, L. H., Burridge, K. and Turner, C. E. (1992). Signaling between the extracellular matrix and the cytoskeleton: tyrosine phosphorylation and focal adhesion assembly. Cold Spring Harbor Symp. Quant. Biol. 57, 193-202.

Romer, L. H., McLean, N., Turner, C. E., Burridge, K. (1994). Tyrosine kinase activity, cytoskeletal organization, and motility in human vascular endothelial cells. Mol. Biol. Cell 5, 349-361.

Rozengurt, E. and Sinnett-Smith, J. (1983). Bombesin stimulation of DNA synthesis and cell division in cultures of Swiss 3 T3 cells. Proc. Nat. Acad. Sci. USA 80, 2936-2940.

Salari, H., Duronio, V., Howard, S. L., Demos, M., Jones, K., Reany, A., Hudson, A. T. and Pelech, S. L. (1990). Erbstatin blocks platelet activating factor-induced protein-tyrosine phosphorylation, polyphosphoinositide hydrolysis, protein kinase $\mathrm{C}$ activation, serotonin secretion and aggregation of rabbit platelets. FEBS Lett. 263, 104-108.

Schaller, M. D., Borgman, C. A., Cobb, B. S., Vines, R. R., Reynolds, A. B. and Parsons, J. T. (1992). pp $125^{\mathrm{FAK}}$, a structurally unique protein tyrosine 
kinase associated with focal adhesions. Proc. Nat. Acad. Sci. USA 89, 51925196.

Seckl, M. and Rozengurt E. (1993). Tyrphostin inhibits bombesin stimulation of tyrosine phosphorylation, c-fos expression, and DNA synthesis in Swiss 3 T3 cells. J. Biol. Chem. 268, 9548-9554.

Seufferlein, T. and Rozengurt, E. (1994). Lysophosphatidic acid stimulates tyrosine phosphorylation of focal adhesion kinase, paxillin and p130. J. Biol. Chem. 269, 9345-9351.

Smith, R. J., Sam, L. M., Justen, J. M., Bundy, G. L., Bala, G. A. and Bleasdale, J. E. (1990). Receptor-coupled signal transduction in human polymorphonuclear neutrophils: effects of a novel inhibitor of phospholipase C-dependent processes on cell responsiveness. J. Pharmacol. Exp. Ther. 253, 688-697.

Tsukita, S., Tsukita, S. and Nagafuchi, A. (1990). The undercoat of adherens junctions: a key specialized structure in organogenesis and carcinogenesis. Cell Struct. Funct. 15, 7-12.

Umezawa, H., Imoto, M., Sawa, T., Isshiki, K., Matsuda, N., Uchida, T., Iinuma, H., Hamada, M. and Takeuchi, T. (1986). Studies of a new epidermal growth factor receptor kinase inhibitor, erbstatin, produced by $\mathrm{MH}$ 435-LF3. J. Antibiot. (Tokyo) 39, 170-173.

Umezawa, K., Hori, T., Tajima, H., Imoto, M., Isshiki, K. and Takeuchi, T. (1989). Inhibition of epidermal growth factor-induced DNA synthesis by tyrosine kinase inhibitors. FEBS Lett. 260, 198-200.

van Corven, Groenink, A., Jalink, K., Eichholtz, T. and Moolenaar, W. H. (1989). Lysophosphatidate-induced cell proliferation: identification and dissection of signaling pathways mediated by $\mathrm{G}$ proteins. Cell 59, 45-54.

van Corven, E. J., Hordijk, P. L., Medema, R. H., Bos, J. L. and Moolenaar, W. H. (1993). Pertussis toxin-sensitive activation of $\mathrm{p} 21^{\text {ras }}$ by $\mathrm{G}$ proteincoupled receptor agonists in fibroblasts. Proc. Nat. Acad. Sci. USA 86, 12591261.

Volberg, T., Geiger, B., Dror, R. and Zick, Y. (1991). Modulation of intercellular adherens-type junctions and tyrosine phosphorylation of their components in RSV-transformed cultured chick lens cells. Cell Regul. 2, 105-120.

Volberg, T., Zick, Y., Dror, R., Sabanay, I., Gilon, C., Levitzki, A. and Geiger, B. (1992). The effect of tyrosine-specific protein phosphorylation on the assembly of adherens-type junctions. EMBO J. 11, 1733-1742.

Whitney, G. S., Chan, P. Y., Blake, J., Cosand, W. L., Neubauer, M. G. Aruffo, A. and Kanner, S. B. (1993). Human T and B lymphocytes express a structurally conserved focal adhesion kinase, pp125 $5^{\mathrm{FAK}}$. DNA Cell Biol. 12, 823-830.

Yaish, P., Gazit, A., Gilon, C. and Levitzki, A. (1988). Blocking of EGFdependent cell proliferation of EGF receptor kinase inhibitors. Science $\mathbf{2 4 2}$, 933-935.

(Received 26 May 1994 - Accepted 9 September 1994)

\section{Note added in proof}

While this manuscript was in preparation, two similar studies by Ridley and Hall (EMBO J. 13, 2600-2610, 1994) and Barry and Critchley (J. Cell Sci. 107, 2033-2045, 1994) were published. These papers reached essentially the same conclusion that a tyrosine kinase is involved in rho-induced formation of stress fibers. This effect of rho can be blocked by a tyrosine kinase inhibitor, genistein, and mimicked by a tyrosine phosphatase inhibitor, vanadyl hydroperoxide. In addition, activation of rhoA was shown to correlate with elevated levels of FAK tyrosine phosphorylation which, in turn, was associated with the formation of focal adhesions and stress fibers. 